る。しかし, 部分ケン化 PVA は残存䣷酸基量とケン化 条件を選び，残存酢酸基の分子内分布を不均一にするこ とで期待することも可能である。

\section{文献}

1）野間夹之, 西浦 脩：高化，7，269(1950)；8，44 (1951)

2）小西 灷，石束哲男：高化，17，125，249(1960)

3）山下雄也, 津田鉄雄, 市川竜夫：工化, 62, 1274 (1958)

4) 和田信明, 井波 章： 油化学, 3, 74(1960)

5) G. F. Biehn, M. L. Erusberger : Ind. Eng. Chem., 40, 1449 (1948)

6) F.H. Winslow, W. Matregek: Ind. Eng. Chem., 43, 1108(1951); 滝川 敏: 工化, 56, 356(1953); S. G. Bankoff, R. N. Shreve: Ind. Eng. Chem., 45, 270(1953); S. G. Bankoff, E. J. Emver: Ind. Eng. Chem., 46, 673(1958)

7）岡村誠三：「乳濁液の合成とその応用」, $101(1949)$
(高分子化学協会); 岡村誠三, 本山卓彦, 山下隆 男：高化，15，170(1958)

8) J. T. O'Donnell, R. B. Mesrobian: J. Polymer Sci., 28, 171(1958)

9）藤井悦男，杉浦正昭：工化，65，1609(1962)

10）杉浦正昭, 藤井悦男：工化，66, 1228(1963)

11) H.L. Frisch, Suham Al-Madfai: J. Am. Chem. Soc., 80, 3561(1958)

12）府川幸資，朝倉忠義，大門 宏：高化，18，596 (1961)

13）松田英臣, 石黒三郎, 栖岡清威, 小寺 明：高化, 12, 10(1955)

14）林 貞男, 中野千世子, 本山卓彦：高化, 20, 303 (1963)

15）畔柳浩二, 桜田一郎：高化，6，419 (1949)

16） JIS，K-3362，(1955）（日本規格協会）

17) 日本化学会編：「化学便筧」，497(1958) (丸善)

18) A. M. Schwartz, J. W. Perry, J. Berch: "Surface Active Agents and Detergents", 2, 153(1957) Interscience Pub.

\title{
The Protective Colloid Properties of Partially Saponified Polyvinyl Acetate
}

\section{The Surface Tensions of Aqueous Solution of Polyvinyl Alcohol}

\author{
By Sadao Hayashi*, Chiyoko Nakano* and Takuhiko Motoyama*
}

\begin{abstract}
The changes of the surface tensions to concentration of aqueous solution of polyvinyl alcohol (PVA) were measured by the drop method. The falls of the surface tensions with perfectly saponified polyvinyl acetate (PVAc) were negligible, and with partially acetylated PVA small. With partially saponified PVAc, the falls of the surface tensions became larger as increasing the residual acetyl contents and with the polymer having maldistributed residual acetyl groups the falls of the surface tensions were great. It is concluded that partially saponified PVAc having hydrophobic ester groups and hydrophilic hydroxyl groups maldistributed in a chain indicates the properties of polymer surface active agents.
\end{abstract}

\section{第 2 報 イェロー $\mathrm{OB}$ の可溶化と金コロイドの保護作用 (1963 年 11 月 29 日受理)}

林貞 男** ・ 中野千世子**・本山卓 彦**

\footnotetext{
要旨ささきに分子内に連綍したエステル基の柾水部分と水酸基の親水部分をもった部分ケン化のポリ ピニルアルコール (PVA) は高分子界面活性剤の性質を保有することを結論した。本報ではこの性貿を油溶性 色素イエローOB の可溶化能と金コロイドについてZigmondy の金数から保護コロイド作用を評価した。完 全ケン化 PVA と均一再酢化 PVA はともにイエローOB の可溶化能は低く, 部分ケン化 PVA は残存酢 酸基量の多いものほど,また残存酢酸基が PVA 分子内に連繶して存在するものほど大きい可溶化能を示した。
}

\footnotetext{
* Research Laboratory, High Polymer Chemical Industries Ltd. (Niwaji, Neyagawa, Osaka)

** 商分子化学工業株式会社研究所 (大阪府寝屋川市仁和寺 434)
} 
金数については完全ケン化 PVA は大きく，重合度の高いものほど小さい值を示した。均一再酢化 PVA は 完全ケン化 PVA とほとんど同じであった。部分ケン化 PVA は他の PVA に比べて金数が小さく保護コ口 イド作用が良好で，残存酢酸基量が多いものほど，残存酢酸基が PVA 分子内に連続したものほど保護コ口 イド作用の大きい結果が得られた。

\section{1. 緒言}

高分子界面活性剤の性能の判定法の一つとして油溶性 色素の可溶化能の測定法が広く利用されている。丸田 ${ }^{1)}$ は完全ケン化のポリビニルアルコール (PVA) のイエロ 一 OB の可溶化能はほとんどないことを認めている。 しかし部分ケン化 PVA についてはなされていない。伊 藤ら ${ }^{2)}$ は部分ヶン化 PVA とドデシル硫酸ナトリウム間 の吸着コンプレックスについて，オレンジ OT の可溶 化能を調べ，顕著な作用を示さないことを報告している が, 部分ケン化 PVA 自体についての実験はなされてい ない。また残存酢酸基量とかその分布などについての考 察は見らけられない。

保護コロイドの作用を比較するのに古くから Zig. mondy の金数が採用されている。PVA の金数について

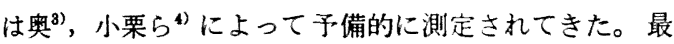
近，藤井ら ${ }^{5)}$ は金コロイド液の塩化ナトリウムによる変 色域の判定に分光光度計を利用して一定波長の透過率か ら金数を測定する方法立提案し，完全ケン化 PVA と部 分ケン化 PVA について詳細に研究を行なった。この報 告によると部分ヶン化 PVA は瑓水基の $-\mathrm{O} \cdot \mathrm{CO} \cdot \mathrm{CH}_{3}$ なる極性基を多く保有するため金コロイド粒子への凝着 はこの双極子ーイオン間の結合によって安定化されるた め完全ケン化 PVAに比べて保護コロイド作用が大きい と説明されている。しかしPVAの分子鎖中に存在する 残存䣫酸基の分布についてはなんら考察はなされていな い。そこでわれわれは, 部分ケン化 PVA がイエロー $\mathrm{OB}$ の可溶化を示すかどうかを残存酢酸基とその分子内 分布について実験し, PVA の金数に及ぼす重合度，ケ ン化度および残存酶酸基の分子内分布の影響について検 討した。

\section{2. 実験}

\subsection{PVA}

\subsection{1 完全ケン化 PVA}

イェローOB の可溶化には前報)の試料を使用した。 重合度は約 500 である。

金コロイドの保護作用にはメタノール系溶液重合より 得た重合度の異なるポリ酢酸ビニル(PVAc) をメタノー ル系でアルカリケン化した。重合度のとくに高いPVA $(\bar{P}=3710,5340)$ は塊状重合より得た PVAcをメ夕， ール采でアルカリケン化した。

\subsection{2 均一再酢化 PVA}

前報) の試料のらち酢酸基含量 14.87 モル\%のもの
を使用した。

\subsection{3 部分ケン化 PVA}

前報6) と同様の試料に必要な試料を追加した。Table 1 にそれらの試料の作製条件と残存酶酸基量およびョー ドとの呈色度 $\mathrm{D} / \mathrm{C}(0.5 \% \mathrm{PVA}$ 水溶液量に対する吸光

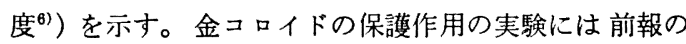
試料（含水量 $3.2 \%$ ) の他に含水量の多い系 $(11.3 \%$ ) で PVAc をケン化し作製した PVA(E-1) を使用した。ケ ン化度と金数の関倸は重合度約 1000 の部分ケン化 PVA を使用した。

\section{2 イエローOB の可溶化測定}

PVA 水溶液 $20 \mathrm{~g}$ を $100 \mathrm{ml}$ のビーカーにとり,これ にイエローOB $0.05 \mathrm{~g}$ を入れてマグネチックスターラ 一で 2 時間十分にかきまぜ，これを試験管に移し 1 週間 $20^{\circ} \mathrm{C}$ の恒温室中に放置する。これを約 $3000 \mathrm{rpm}$ の遠 心分離器に 2 時間かけて 不溶色素を分離し, $450 \mathrm{~m} \mu$ の 波長での吸光度を測定, 相対的な可溶化量の目安とした。 装置は日立 EPU-2 A 型, セル幅 $10 \mathrm{~mm}$ 。

\section{3 金コロイドの作製》}

塩化金 $\left(\mathrm{AuCl}_{4} \mathrm{H} \cdot 4 \mathrm{H}_{2} \mathrm{O}\right)$ の結晶 $1 \mathrm{~g}$ 蒸留水 $150 \mathrm{~m} l$ に溶かし，炭酸カリウム $12 \mathrm{~g}$ を蒸留水 $100 \mathrm{ml}$ に溶か す。金溶液 $25 \mathrm{~m} l$, 炭酸カリウム溶液 $3.5 \mathrm{~m} l$, 蒸留水 $120 \mathrm{ml}$ をとり, これにバーナーの炎をあてて梁赤色の 金コロイドを得た。

\section{4 金数の測定}

金コロイド $10 \mathrm{ml}$ を数本の試験管にとり,これに PVA 水溶液をピペットで順次添加し(その添加量を $0.1 \sim 1.0 \mathrm{~m} l$ の範囲) 全量を $11 \mathrm{~m} l$ になるように蒸留水 を添加する。次に $10 \%$ 塩化ナトリウム水溶液 $1 \mathrm{~m} l$ を 加え, 変色しないPVA の最低添加量を求め,この $\mathrm{mg}$ 数 を金数とし金数の逆数をもって保護度として表示した。

\section{3. 実験結果および考察}

\section{1 イエローOB の可溶化}

イエローOBを $1: 3$ の水一メタノル混合溶液に溶 解して, 吸光度を測定すると Fig. 1 の上うに $440 \mathrm{~m} \mu$ に極大吸収がある。部分ヶン化 PVA にイエローOB を可溶化し,この吸収波長を求めると極大吸収は $450 \mathrm{~m} \mu$ にある。これを水一タノールの比が $1: 3$ になるよう に希釈するとイェロー OB の水一メタノル溶液と同じ $440 \mathrm{~m} \mu$ に極大吸収が移行する。Saito ${ }^{8)}$ はポリビニルピ ロリドン,メチルセルロースなどのポリマーについてド デシル硫酸ソーダ共存系でのイエローOB の可溶化を 測定し, 極大吸収波長の長波長側への移行は分子内に強 
Table 1. Saponified conditions of PVAc and the properties of PVA.

\begin{tabular}{|c|c|c|c|c|c|c|c|}
\hline \multirow{2}{*}{ Sample } & \multicolumn{4}{|c|}{ Conditions of saponification } & \multicolumn{3}{|c|}{ Properties } \\
\hline & $\begin{array}{l}\text { PVAc con- } \\
\text { tents }(\%)\end{array}$ & $\begin{array}{l}\text { Methanol } \\
\quad(\%)\end{array}$ & $\begin{array}{l}\text { Benzene } \\
(\%)\end{array}$ & $\begin{array}{l}\text { Water } \\
(\%)\end{array}$ & $\begin{array}{c}\text { Residual acetyl } \\
\text { contents }(\%)\end{array}$ & $\mathrm{D} / \mathrm{C}^{*}$ & $\tan \theta^{* *}$ \\
\hline A-4 & 16.1 & 80.7 & 0 & 3.2 & 7.78 & 0.01 & 0.2 \\
\hline$A-7$ & $n$ & $"$ & $"$ & $"$ & 12.80 & 0.11 & 0.7 \\
\hline A-8 & $"$ & $"$ & $"$ & $"$ & 16.50 & 0.22 & 1.6 \\
\hline A-9 & $"$ & $"$ & $"$ & $"$ & 24.35 & 0.59 & 6.3 \\
\hline B-1 & 16.1 & 64.6 & 16.1 & 3.2 & 6.80 & 0.02 & 0.4 \\
\hline B-2 & $n$ & $"$ & $"$ & $"$ & 9.33 & 0.07 & 0.4 \\
\hline B -4 & “ & $"$ & $"$ & $"$ & 14.62 & 0.22 & 1.5 \\
\hline B-5 & $"$ & $"$ & $"$ & $"$ & 16.52 & 0.30 & 2.9 \\
\hline$C-1$ & 16.1 & 48.5 & 32.2 & 3.2 & 5.58 & 0.04 & 0.4 \\
\hline C -2 & $"$ & $"$ & $"$ & $"$ & 8.63 & 0.12 & 0.9 \\
\hline$C-4$ & $"$ & $"$ & $"$ & $"$ & 11.75 & 0.26 & 2.1 \\
\hline$C-5$ & $"$ & $"$ & $"$ & $"$ & 16.35 & 0.48 & 4.6 \\
\hline D -2 & 16.1 & 32.4 & 48.3 & 3.2 & 5.56 & 0.15 & 2.3 \\
\hline$D-3$ & $"$ & $"$ & $"$ & $"$ & 8.10 & 0.41 & 3.8 \\
\hline$D-5$ & $"$ & $n$ & $"$ & $"$ & 13.62 & 0.57 & 9.0 \\
\hline$D-6$ & $"$ & $n$ & $"$ & $"$ & 16.58 & 0.85 & 15.6 \\
\hline $\begin{array}{l}\text { Perfectly saponi- } \\
\text { fied PVAc }\end{array}$ & 16.1 & 80.7 & 0 & 3.2 & 0.42 & - & 0.2 \\
\hline $\begin{array}{l}\text { Partially acetylated } \\
\text { PVA }\end{array}$ & - & - & - & - & 14.87 & - & 0.4 \\
\hline
\end{tabular}

* $\mathrm{D} / \mathrm{C}=$ Adsorbance $/ 0.5 \%$ PVA aq. soln. cc, ${ }^{* *} \tan \theta=$ Adsorbance/PVA g

い極性基をもつものほど大きいことを明らかにした。こ のことからメタノールに溶解したイェローOB の吸収 よりも部分ヶン化 PVA に可溶化したものの吸收が上述 したよ5に，長波長側に移行した原因はPVA 中の残存 酢酸基の極性基によるものと思われる。可溶化された色 素の吸光度は経時変化を伴うともいわれ，可溶化状態で の吸光度から可溶化量を求めることは繳密には正しくは ない。そのために一般には可溶化された色素をメタノー ルに溶解して測定されている。しかし，本実験では普通 の PVA のイェローOB の可溶化能が 小さいためにメ タノールで希釈するとますます測定が困難になること， 完全ケン化 PVA あるいは残存酡酸基量の少ない部分ケ ン化 PVA はメタノールで疑析するので, 可溶化した後 メタノールで希䣋せずにそのまま $450 \mathrm{~m} \mu$ の波長で吸 光度を測定し，その吸光度をもって相対的な可溶化能の 目安として評価した。なお，本実験結果はイエローOB の水への溶解量は少ないために補正はされていない。 完全ケン化, 均一再酢化および部分ケン化 PVA につ

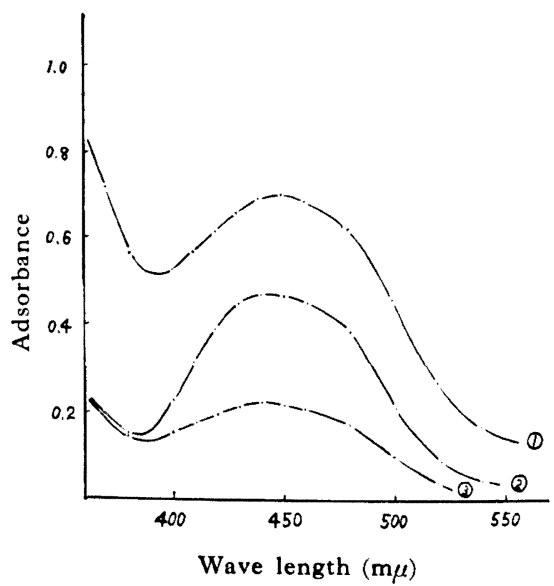

(1): Yellow OB-partially saponified PVAc, (2): Yellow OB-methanol, (3): Yellow OB-partially saponified PVAc-methanol

Fig. 1. Adsorption of Yellow OB solubilized by PVA. 
レてのイエローOB の可溶化能を示すと Fig. 2 のごと くである。完全ケン化, 均一再酢化 PVA はともにほと んど可溶化能を示さないが, 部分ケン化 PVA には顕著

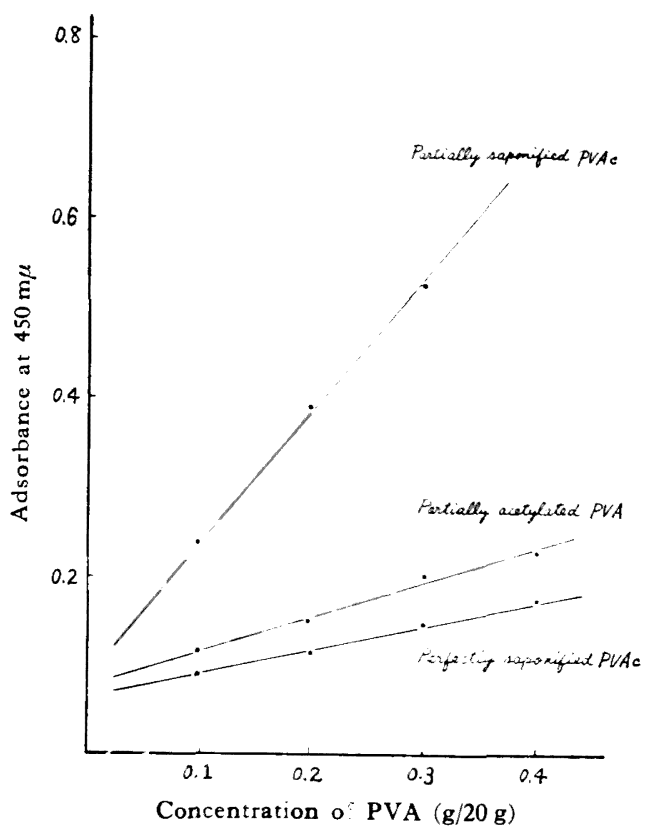

Fig. 2. The solubilizations of Yellow OB by PVA.

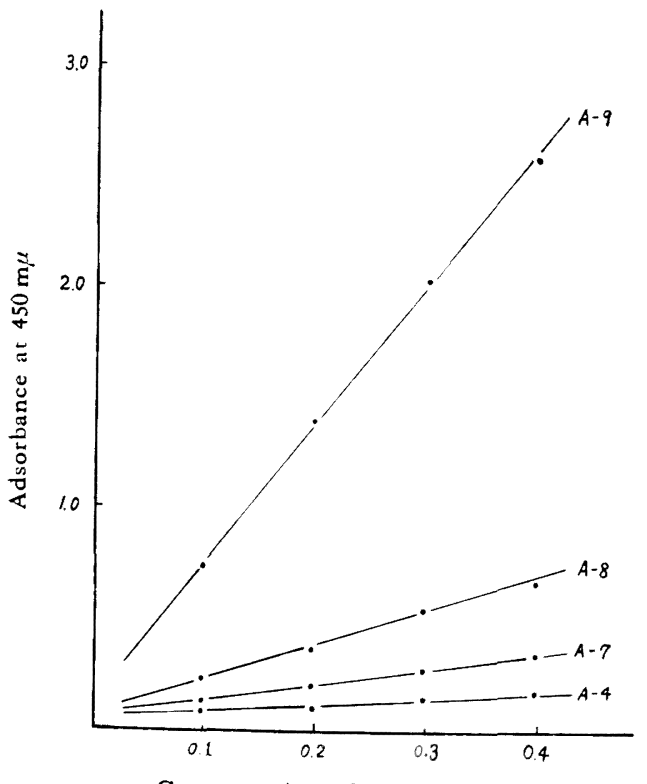

Concentration of PVA $(\mathrm{g} / 20 \mathrm{~g})$

Fig. 3. The solubilizations of Yellow OB by PVAc saponified partially in methanol solvent.
な可溶化現象が見られた。部分ケン化 PVA が著しい可 溶化能を有寸る原因が残存酶酸基量によると考えるなら ば, 均一再酢化 PVA も部分ヶン化 PVA と同様可溶化 の現象を示してもよいはずである。ところが Fig. 2 の ように均一再酢化 PVA は完全ケン化 PVA とほとんど 同じく可溶化能は乏しい。これはやはり PVA 分子内の 残存酢酸基の分布が大きく影響していると考えられる。

次に残存酢酸基量の異なる PVA について実験した。 A-系試料の結果を Fig. 3 に示す。A-系試料はメ夕, ール采でアルカリ量を変えて PVAc をケン化した普通 のPVA である。残存酶酸基量が多くなるにつれてイエ 口- OB の可溶化量も增大寸る。試料 A-9 は残存酶酸

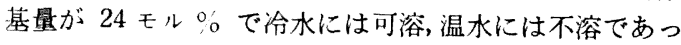
た。PVAcのケン化時に多量のベンゼンを添加してつ くった D-采試料について同じくイエロー OB の可溶化 量党測定した結性在Fig. 4 亿示す。A-系試料と同じよ うに残存酢酸基量とともにイェロー OB の可溶化量は 增加し, 残存酢酸基量の多い試料はその可溶化量が著し く增加する。また A-系試料に比べて顕著な可溶化能を 有する。さらに PVAc のケン化時の添加ベンゼン量を

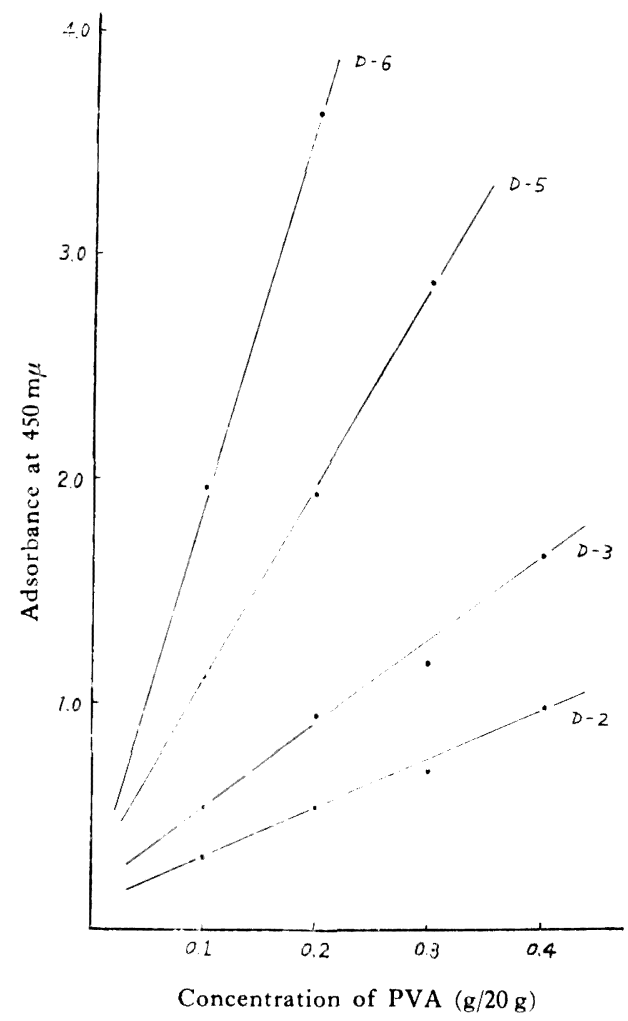

Fig. 4. The solubilizations of Yellow $O B$ by PVAc saponified partially in methanol-benzene solvent. 


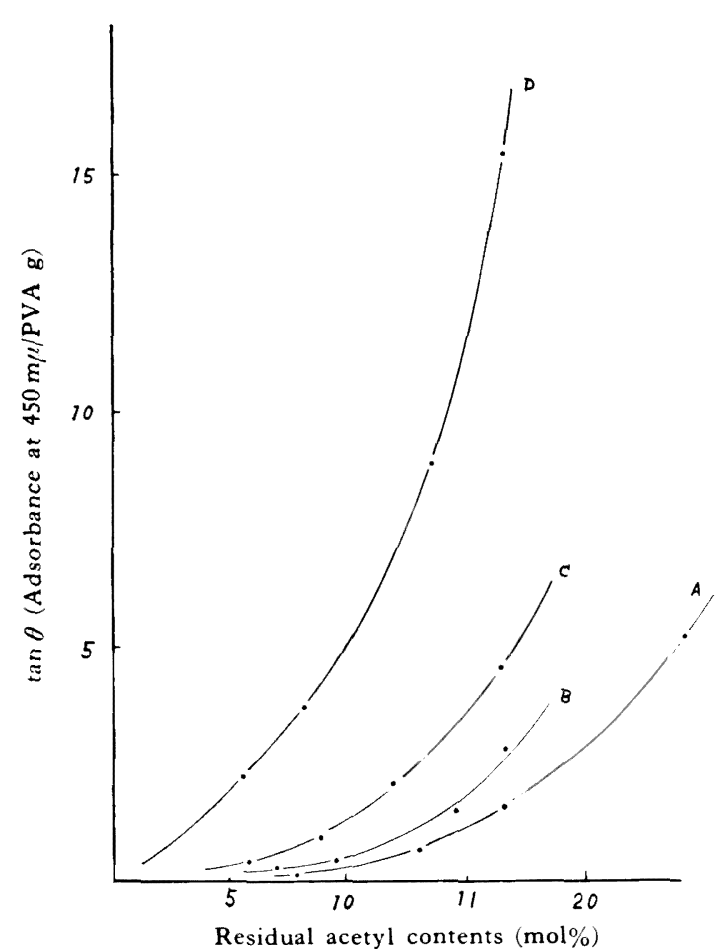

Fig. 5. The relation between $\tan \theta$ and residual acetyl contents.

変えた $\mathrm{B}, \mathrm{C}$-系試料についてのイエロー $\mathrm{OB}$ の可溶化 能の結果を Table 1 と Fig. 5 に A, D-采試料ととも にまとめた。Fig. 5 は PVA 濃度に対する可溶化能 (吸 光度/PVA $(\mathrm{g})=\tan \theta)$ と残存酢酸基量との関係である。 この関倸曲線は $\mathrm{A}, \mathrm{B}, \mathrm{C}, \mathrm{D}$-采試料の順に上部に移動 している。すなわち PVAc のケン化時のベンゼン含有 量の多いPVA ほどイェローOB の可溶化量が大きい。 また残存酷酸基量が増すと $\tan \theta$ の值，すなわちイェ口 一 OB の可溶化量が急激に增加寸る。この傾向は PVAc のケン化時のベンゼン含有量の多い系の PVA ほど大 きい。

丸田9 はポリオキシェチレンドデシルェーテルのイエ ロー OB の可溶化量を調べ,イェロー OB のような油 溶性色素は界面活性剤のミ七ル内部に可溶化されるもの で，可溶化に対してはアルキル基が必要であって親水性 部分の大小には無関倸で，大体モルあたり一定であるこ とを見出した。また斎藤ら ${ }^{10)}$ はスチレンーマレイン酸の 共重合体を母体とするエステル化物の高分子界面活性剂 について研究し、このポリマー水溶液のイエローOB の 可溶化能はエステル基, エステル化度㧍よび丹体のポリ マーの重合度が影響するが，とくにアルキル鎖長は可溶 化に大きく影響を及ぼすことを明らかにした。
これらの考察に基いて部分ケン化 PVA の挙動を考察 すると部分ケン化 PVA がイエローOB を可溶化する 現象は, 分子内に柾水部分を所有するためと推察される。 PVAc のメタノール系でのケン化機構は原理的に残存 酢酸基が分子鎖に沿って連続して存在する傾向にあるの で，この連続した残存酢酸基が蹯水部分として作用する ためにこれによってイェローOB の可溶化が起こると 考えられる。ヨード法 ${ }^{11}$ によって PVA 分子内の残存 酢酸基の分布を調べると残存酢酸基が分子内に連続して いるものほどョード呈色度が大きく，残存酶酸基が分子 内に均一に分布した均一再酢化 PVA は呈色しない。残 存酢酸基が少ないPVA はヨード呈色は小さく残存酢酸 基を增すと增加する。これは分子内の残存酢酸基分布の 不均一度が残存酢酸基量の增加につれて急激に増加する 傾向にあるためである。PVAc をケン化するときにべ ンゼンを添加すると，ケン化反応がよりマク口的に起こ るために残存酶酸基は分子内に連続して存在するような 傾向になり, Table 1 に示したように PVA のヨード 呈色度 $\mathrm{D} / \mathrm{C}$ は $\mathrm{A}<\mathrm{B}<\mathrm{C}<\mathrm{D}$-系試料の順に大きく, こ の順序に分子内の 残存酢酸基が 不均一に分布している。 そこでこのヨード呈色度とこれらの試料のイエローOB の可溶化能の結果を Table 1 あるいは Fig. 5 から比 較するとヨード呈色度の高いPVA はイエローOBの 可溶化能も高い值を示している。したがってPVA 分子 内に連なって存在する残存酢酸基の疎水部分がイエロー OB の可溶化に寄与したと考えられる。Donnell ら ${ }^{12)}$ は 光散乱から PVA の分子間ミ七ルを否定している。これ からすれば PVA の溶存状態では分子間の酢酸基の集合 は起こらないために, 低分子活面活性㓮のような分子間 ミセル内へのイエロー OB の可溶化はない。したがっ て部分ケン化 PVA に可溶化したイェローOB の極大 吸収波長が、メタノールに溶解したそのものよりも長波 長側に移行したことから部分ケン化 PVA のイェロー $\mathrm{OB}$ の可溶化は色素がポリマー分子内の極性基である酢 酸基に吸着され，しかも極性基がポリマー分子内に連続 しているものほど色素の吸着量を増大寸るものと考えら れる。

\section{2 金コロイドの保護作用}

完全ケン化 PVA の金コロイドの保護度は一般に悪 い。重合度と金数, 保護度の関係を Table 2 に示す。 重合度が大きくなると金数が小さくなり, 保護度は増大 する。

残存酷酸基量については重合度約 1000 の試料を使つ て測定した結果を Table 3 に示す。残存酢酸基量が増 すほど金数は小さくなって保護度は增大寸る。この関倸 は Fig. 6 のごとくである。

PVA 分子内の 残存酢酸基分布の影響について重合度 約 500 の完全ケン化, 均一再酢化と部分ヶン化 PVA の 
Table 2. Relation between degree of polymerization of PVA and gold number.

\begin{tabular}{c|c|c|c}
\hline Sample & $\begin{array}{c}\text { Degree of } \\
\text { polymeri- } \\
\text { zation of } \\
\text { PVA }\end{array}$ & Gold & $\begin{array}{c}\text { Degree of pro- } \\
\text { tection (the } \\
\text { reciprocal of } \\
\text { gold number) }\end{array}$ \\
\hline & 85 & 110 & 0.0091 \\
Solution & 110 & 71 & 0.014 \\
polymeri- & 195 & 46 & 0.022 \\
zation & 570 & 30 & 0.033 \\
& 970 & 17 & 0.059 \\
& 1460 & 3.0 & 0.077 \\
& 2100 & 2.1 & 0.20 \\
Bulk & 3710 & 1.2 & 0.33 \\
polymeri- & 5340 & 0.9 & 0.48 \\
zation & 560 & 1.1 \\
\hline
\end{tabular}

Table 3. Relation between degree of saponification of PVAc (PVA $\bar{P} \fallingdotseq 1000)$ and gold number.

\begin{tabular}{c|c|c}
\hline $\begin{array}{c}\text { Degree of } \\
\text { saponification }\end{array}$ & Gold number & $\begin{array}{c}\text { Degree of protec- } \\
\text { tion (the reciprocal } \\
\text { of gold number) }\end{array}$ \\
\hline 100 & 5.0 & 0.20 \\
97.9 & 3.1 & 0.32 \\
94.0 & 1.8 & 0.56 \\
91.9 & 0.20 & 5.0 \\
88.2 & 0.18 & 5.6 \\
\hline
\end{tabular}

結果を Table 4 に示す。均一再酢化 PVA は完全ケン 化 PVA とほとんど同じ金数を示したが, 部分ヶン化 PVA の場合は PVAc のケン化時の ンンゼン含有量が

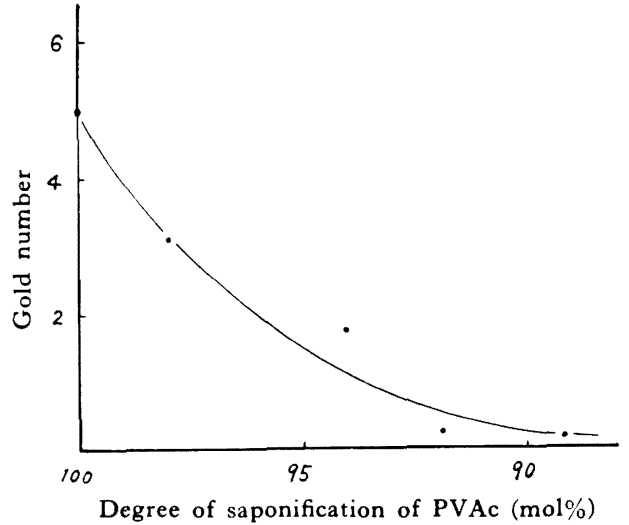

Fig. 6. The relation between gold number and degree of saponification of PVAc.

多い試料ほど 金数は小さく, 含水量の多い采で PVAc をケン化してつくった PVA (E-1) は大きい金数を示 した。

一般にポリマーの吸着量は重合度が高くなるにつれて 多くなる傾向にあるといわれている。Heller ら ${ }^{18)}$ はポ リエチレンオキサイドによる金コロイドの保護作用を詳 細に研究し, 重合度が低い範囲ではその作用は低く, 重 合度が高くなると急激に上昇することを明らかにした。 この理由としてポリマーの吸着は分子の 1 点かあるいは 2 点で起こると考えて, 吸着されたポリマーの粒子表面 に存在する層の厚さが, 重合度の高いポリマーほど厚く 形成されるためであると述べている。PVA においても Heller らの考察をもってすれば重合度の高、PVA ほ ど金コロイドの保護作用が大きく現われた結果を理解す ることができる。

Table 2 の重合度と金数の関係を対数でプロットする と Fig. 7 のごとくほぼ直線関係が得られ, 次式が近似 的に成立する。

Table 4. Relation between partially saponified PVAc, partially acetylated PVA, (respectively $\bar{P} \fallingdotseq 500$ ) and gold number.

\begin{tabular}{c|c|c|c|c}
\hline Sample & $\begin{array}{c}\text { Residual acetyl } \\
\text { contents }(\mathrm{mol} \%)\end{array}$ & $\mathrm{D} / \mathrm{C}^{*}$ & Gold number & $\begin{array}{c}\text { Degree of protective (the } \\
\text { reciprocal of gold number) }\end{array}$ \\
\hline E-1 & 10.48 & 0.05 & 0.9 & 1.1 \\
A-6 & 10.28 & 0.05 & 0.7 & 1.4 \\
B-3 & 10.15 & 0.10 & 0.4 & 2.5 \\
C-3 & 9.23 & 0.15 & 0.3 & 3.3 \\
D-4 & 10.45 & 0.41 & 28 & 3.3 \\
Partially acetylated PVA & 14.87 & - & 24 & 0.036 \\
Perfectly saponified PVAc & 0.42 & - & 0.042 \\
\hline
\end{tabular}

* $\mathrm{D} / \mathrm{C}=$ Adsorbance $/ 0.5 \%$ PVA aq. soln. cc 


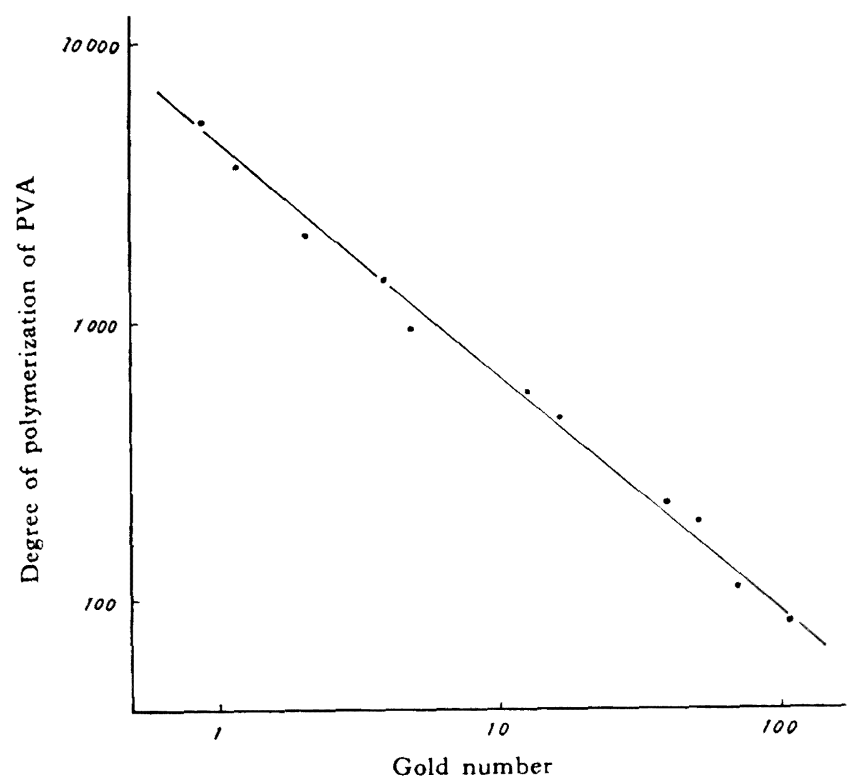

Fig. 7. The relation between gold number and degree of polymerization of PVA.

$$
\begin{gathered}
\log N=4.2-1.2 \log \bar{P} \\
\text { だしし } N: \text { 金数 } \\
P: \text { 完全ヶン化 PVA の重合度 }
\end{gathered}
$$

ケン化度の影㗽については藤井ら ${ }^{5)}$ が認めているよう に残存酢酸基が存在すると金数が小さくなり，保萑コ口 イドの作用は大きくなる。この理由について藤井らは PVA は炭素原子 1 個おきに $-\mathrm{OH}$ 基を有し，水分子と の結合力が蹯水コロイド面との結合力より強固で水和層 を形成し，水分子を介在しての定着と考えられ，それゆ え部分ヶン化 PVA においては親水基 $\mathrm{OH}$ の代わりに 柾水性の $-\mathrm{O} \cdot \mathrm{CO} \cdot \mathrm{CH}_{3}$ なる極性基をかなり多く保有す るために, 界面への凝省はこの双極子一イオン間の結合に よってかえって安定なものとなるためであると考察して いる。

この考察に基いて部分ケン化 PVA が金コロイドを安 定化するとすれば，残存酢酸基量が増加するほど，保護 コロイドの作用効果は顕著に現われるはずである。Fig. 6 に見られるように残存酢酸基量の增加とともに金数は 低下し,この考察がよく説明されているように思われる。 しかし, 部分ケン化 PVA と称されるものも分子内の残 存酢酸基の分布は種々異なった状態にある。われわれは さきに残存酢酸基分布の度合を相対的に考察できるヨー ド法"1)を提出した。それに基いて残存酶酸基量がほぼ同 しで残基酢酸基の分子内分布の異なる PVA をつくり,
残存酢酸基の分子内分布の度合と金コロイドの 保護作用の関係を調べてみた。

その結果が Table 4 である。Table 4 のョ

ード呈色度 D/C の関係から PVAc のケン化 時のベンゼン含有量の多い系でつくった PVA ほど，残存䣫酸基は分子鎖に沿って連続してお り，含水量の多い系でつくった PVA (E-1) は 比較的に均一である。したがって部分ケン化 PVA 試料は $\mathrm{E}<\mathrm{A}<\mathrm{B}<\mathrm{C}<\mathrm{D}$ の順に残存酢 酸基が分子鎖に沿って連続し，金コロイドの保 護作用もこの順序に良好な数值を示している。 また均一再酢化 PVA は完全ヶン化 PVA と ほとんど同じ程度の保護コロイド作用しか示さ ない。もし藤井らの考察のように部分ケン化 PVA 中の $-\mathrm{O} \cdot \mathrm{CO} \cdot \mathrm{CH}_{3}$ の極性基が 双極子-1 オン間の結合で金コロイドの保護作用を示すも のであれば，均一再酢化 PVA は完全ヶン化 PVA に比べて強固な保護コロイド作用を保持 しなければならないであろう。また残存酶酸基 が分子鎖に沿って連続している PVA ほど金数 が低いことからも, 部分ケン化 PVA の金ュロ イドの保变作用は単に酢酸基によるものである と哾明することはできない。酶酸基と金コロイドの双極 子ーイオン間の結合が保萑コロイド作用の支配的なもの ではないと考えられる。

前報6)で述べたように，もし PVA 中の酢酸基が分子 鎖に沿って無秩序に分布しているならば，その水溶液の 濃度に対する表面張力の低下はわずかで界面活性ではな い。ところが部分ケン化 PVA，とくに残存酢酸基が分 子鎖に沿って連続している PVA ほど界面活性が大であ った。またさきに認められたようにイェローOBの可 溶化能なども高い值を示した。これらのことからも部分 ケン化 PVA の金コロイドの保護作用は完全ケン化, 均 一再酢化 PVA に比べてすぐれている理由として, PVA 分子鎖に沿って連続している残存酢酸基が柾水部分とし て，水酸基の分子内の連続した部分が親水部分として高 分子界面活性剤としての作用が強く働いているものと推 察される。

Fig. 6 のように残存酢酸基量の多いPVA ほど金数 が小さく保護度が高いことは, 普通のケン化条件でつく られた部分ケン化 PVA 中の残存酢酸基がその量を増加 するほど，分子鎖に沿って連続して存在するようになる ために保護コロイド作用が大きく現われたもので, 残存 酢酸基量が增加した理由だけではないと考えられる。

\section{文献}

1) 丸田 箃: 日化, 83, 395(1962)

2) 伊藤浩一，山下婎也：油化学, 11, 373(1962) 
3) 奥 正巳：㵶学誌, 8, 21(1952)

4) 小栗搭蔵, 小野 隆：高化, 9, 44(1952)

5）藤井悦男，杉浦正昭：工化，65，1609(1962)

6) 林 貞男, 中野千世子, 本山卓彦：高化, 21, 300 (1964)

7）鮫島実三郎：「物理化学実験法」，391(1941) 裳華 房

8) S. Saito: Kolloid, Z., 154, 19(1957)
9) 丸田 厳: 日化, 83, 861(1962)

10）斎藤義衛, 砂沢裕寿: 工化，66，489(1963)

11）林 貞男, 中野千世子, 本山卓彦：高化, 20,303 (1963)

12) J. T. O'Donnell, R. B. Mesrobian: J. Polymer Sci., 28, 171(1958)

13) W. Heller, T. L. Pugh: J. Polymer Sci., 47, 203 (1960)

\section{The Protective Colloid Properties of Partially Saponified Polyvinyl Acetate}

\section{The Solubilization of Yellow $\mathrm{OB}$ and the Protective Effects on Gold Colloid}

By Sadao Hayashi*, Chiyoko Nakano* and Takuhiko Motoyama*

It was previously reported that partially saponified polyvinyl acetate (PVAc) which had hydrophobic ester groups and hydrophilic hydroxyl groups maldistributed in a polymer chain indicated the properties of polymer surface active agents. The present investigation was undertaken to make clear the effects of polyvinyl alcohol (PVA) on the solubilization of oil soluble colour, Yellow $\mathrm{OB}$ and on gold colloid.

With both perfectly saponified PVAc and partially acetylated PVA, the solubilization of Yellow OB were low. With partially saponified PVAc, the solubilization of Yellow OB became higher as the residual acetyl contents were increased and the residual acetyl groups were maldistributed in a polymer chain.

Perfectly saponified PVAc indicated large gold number and the higher the degree of polymerization, the smaller the gold number. Partially acetylated PVA was almost same as perfectly saponified PVAc. Partially saponified PVAc had the excellent protective effects than other PVAs and the more its residual acetyl contents and maldistribution of residual acetyl groups in a polymer, the smaller the gold number.

\footnotetext{
* Research Laboratory, High Polymer Chemical Industries Ltd. (Niwaji, Neyagawa, Osaka)
} 